April - 2003

\title{
Learner Support Services for Online Students: Scaffolding for success
}

\author{
Stacey Ludwig-Hardman \\ Western Governors University, USA \\ Joanna C. Dunlap \\ University of Colorado at Denver, USA
}

\begin{abstract}
A critical component of an effective retention program for online students is a learner support services program. While many factors contribute to attrition, at the top of the list are level of interaction and support. To this end, some students in distance learning programs and courses report feelings of isolation, lack of self-direction and management, and eventual decrease in motivation levels. This article describes the types of learner support services strategies that can effectively address these retention challenges. Examples from Western Governors University (WGU) are provided to describe these strategies in action.
\end{abstract}

Keywords: learner support; online learning; scaffolding; self-directed learning; isolation; learning community; advising

\section{Introduction}

Distance learning opportunities for students have skyrocketed in popularity. Every year, more universities are starting online programs. Much of this increase is due to the demands of the learner audience who are intrigued by distance education, mostly because they face a number of obstacles that make conventional, brick-and-mortar educational options unviable:

- They live in remote geographic areas

- Conveniently located institutions offer limited program options

- Their work schedules conflict with campus-bound course schedules. This includes people who work shifts, travel frequently on business, work long hours, and/ or are in the armed forces

- Personal and family commitments conflict with campus-bound course schedules. This includes having children at home and taking care of aging parents

These obstacles make online learning opportunities attractive - in fact, the obstacles create a built-in audience for online education providers. However, drop out rates associated with distance learning typically range from 20 to 50 percent (Brawer, 1996; Carr, 2000; ERIC, 1984; Kerka, 1995; Parker, 1999). More often than not, distance learning programs report greater attrition rates than traditional on-campus programs. The challenge for online education providers therefore, is 
Ludwig-Hardman \& Dunlap Learner Support Services for Online Students: Scaffolding for success

not so much how to recruit students, but how to retain them once they have begun. Learner support services are thus a critical component of an effective retention program.

\section{A Challenge for Online Education Providers}

While many factors contribute to online student attrition, at the top of the list are level of interaction and support (Moore and Kearsley, 1996). According to Abrami and Bures (1996) some students in distance learning programs and courses report feelings of isolation, lack of selfdirection and management, and eventual decreases in motivation levels. These factors are supported by Tinto's (1997) model of institutional departure with its central notion that student persistence is strongly predicted by their degree of academic integration (e.g., performance, academic self esteem, identity as a student, etc.) and social integration (e.g., personal interaction, connection to academic community, etc.).

One of the most consistent problems associated with distance learning environments is a sense of isolation due to lack of interaction (Bennett, Priest and Macpherson, 1999; Harasim, Hiltz, Teles and Turoff, 1995). This sense of isolation is linked with attrition, instructional ineffectiveness, failing academic achievement (Booher and Seiler, 1982), and negative attitudes and overall dissatisfaction with the learning experience (Thompson, 1990). Online learners can easily feel isolated if they do not feel connected to both the greater (university-level) and local (programand course-level) social context (Abrahamson, 1998; Besser and Donahue, 1996; Brown, 1996; Rahm and Reed, 1998). This can negatively affect retention - students may drop out of a program or course because they do not feel part of a community (DeVries and Wheeler, 1996).

Closely associated with retention is student satisfaction with distance delivered courses. While some studies have reported high satisfaction from learners in online courses (i.e., Hill, 1999; Hill, Rezabek and Murry, 1998; Wayland, Swift and Wilson, 1994), others have indicated that students often experience frustration with distance delivered courses because they do not possess the skills needed to be successful (Ritchie and Newby, 1989; Swift, Wilson and Wayland, 1997). In fact, students' feelings of isolation can be compounded if they are ill equipped to deal with the demands of studying at a distance. Some students do not possess is the self-directed skill set, specifically: self-discipline, the ability to work alone, time management, learning independence, the ability to develop a plan for completing work, and so on (Burak, 1993; Dunlap and Grabinger, 2003; Hancock, 1993; Piskurich, 2002). Although often described as a hallmark of adulthood, some people are not self-directed learners (Kerka, 1994). In specifying "successful online learner" guidelines and assessment tools, online education providers list self-direction as a primary quality of successful online learners (e.g., http://www.Colorado.edu/cewww/Fac101/success4.htm, http://ace.coe.wayne.edu/guidelines.html and http://www.ion.Illinois.edu/IONresources/onlineLearning/StudentProfile.html). Compounding the challenge faced by students who feel isolated and disconnected is that selfdirected learning skills are developed in a social context (Dunlap and Grabinger, 2003; Kerka, 1999; Long, 1994) through a variety of human-oriented interactions with peers and colleagues, teams, informal social networks, and communities of practice (Kerka, 1994).

Clearly, there is an expectation in distance and online learning programs that learners take on a high level of responsibility and initiative for their own learning (McLoughlin and Marshall, 2000). As Knowles described in his text on self-directed learning (Knowles, 1975, p. 15), "students entering these programs without having learned the skills of self-directed inquiry will experience anxiety, frustration, and often failure ..." To be successful, learners need the skills required for effective online learning, and those skills need to be explicitly taught and supported 
Ludwig-Hardman \& Dunlap Learner Support Services for Online Students: Scaffolding for success

in the online learning environment. These challenges to the retention of distance learners, interestingly enough, have something in common: they seem to hinge on learners' need for significant support in the distance learning environment through interaction with others (e.g., peers, instructors, and learner support services personnel).

\section{Scaffolding as a Conceptual Framework for Learner Support Services}

Tait (2000) describes the central functions of learner support services for students in distance education settings as cognitive, affective, and systemic. Most descriptions of learner support services focus on systemic characteristics - access to the administrative processes and procedures of the educational provider in a timely and accurate manner (e.g., how to register for courses, tracking individual progress on a degree plan, etc.). What is often ignored, however, is the cognitive function of learner support services, such as guidance, counseling, assessment, coaching, etc. A focus on cognitive outcomes - in particular that learners have various needs, including the need to belong, to interact with each other, and to be a part of a community (Maslow, 1987; Stacey, 1999; Vygotsky, 1978) - leads to creating a learner support services program "where students feel at home, where they feel valued, and which they find manageable" (Tait, 2000, p. 289). Providing this type of support requires more than a technical infrastructure to serve up Web pages on demand - it requires three interrelated elements (Thorpe, 2001):

- Identity. The learner has the opportunity to interact with learner support services personnel on a one-to-one basis

- Individualization. The interaction that the learner has with learner support services personnel is individualized, based on the specific needs and goals of the learner

- Interpersonal interaction. The interaction is mutual and reciprocal, with learning and performance as goals rather than simply information delivery

In a learner support services environment, these elements can be realized through the practice of scaffolding.

The concept, or metaphor, of scaffolding (Wood, Bruner and Ross, 1976) is grounded in the developmental theories of Vygotsky (1978), specifically his concept of assisted learning as described by the "zone of proximal development" (ZPD). The ZPD is:

... the difference between the child's developmental level as determined by the independent problem solving and the higher level of potential development as determined through problem solving under adult guidance or in collaboration with more capable peers. (Vygotsky, 1978, p. 86)

Although the concept of ZPD and the scaffolding metaphor were originally used to describe child development, the current view of the ZPD has extended beyond child-adult and novice-expert interaction to include a view that describes the ZPD as "an opportunity for learning with and from others that applies potentially to all participants, and not simply to the less skillful or knowledgeable” (Wells as cited in Anton, 1999). As such, the notions of the ZPD and scaffolding are helpful in considering the support services needs of learners in distance learning settings. Learner support services, if focused on the cognitive features that Tait (2000) describes, can serve 
to assist performance through the ZPD by promoting a potential for success in a distance learning setting founded on interaction between learners and support services personnel.

Scaffolding involves providing learners with more structure during the early stages of a learning activity and gradually turning responsibility over to them as they internalize and master the skills needed to engage in higher cognitive functioning (Palincsar, 1986; Rosenshine and Meister, 1992). Scaffolding has a number of important characteristics (Greenfield, 1984; McLoughlin and Mitchell, 2000; Wood et al., 1976) to consider when determining the types of learner support services distance students may need:

- Provides structure

- Functions as a tool

- Extends the range of the learner

- Allows the learner to accomplish a task that would otherwise not be possible

- Helps to ensure the learner's success

- Motivates the learner

- Reduces learner frustration

- Is used, when needed, to help the learner, and can be removed when the learner can take on more responsibility

Looking at this list it is clear that the practice of scaffolding is an inherently social process in which the interaction takes place in a collaborative context. The remainder of this article describes how the Western Governors University's learner support services program uses a collaborative context (such as learning communities, advising, and other interactions) to achieve the level of scaffolding needed to address the retention challenges of isolation and lack of needed self-directed learning skills.

\section{Learner Support Services Designed to Support Learners' Self-Direction and Interaction}

In order to provide learner support services that help students successfully participate in online learning courses and programs, Western Governors University (WGU) has employed strategies that reflect the collaborative context needed for effective scaffolding. These interactive strategies, which provide the scaffolding needed to enhance students' self-directed learning skills and reduce their feelings of isolation, are summarized in Table 1. 
Ludwig-Hardman \& Dunlap Learner Support Services for Online Students: Scaffolding for success

Table 1. Learner Support Services Strategies for Self-direction and Interaction

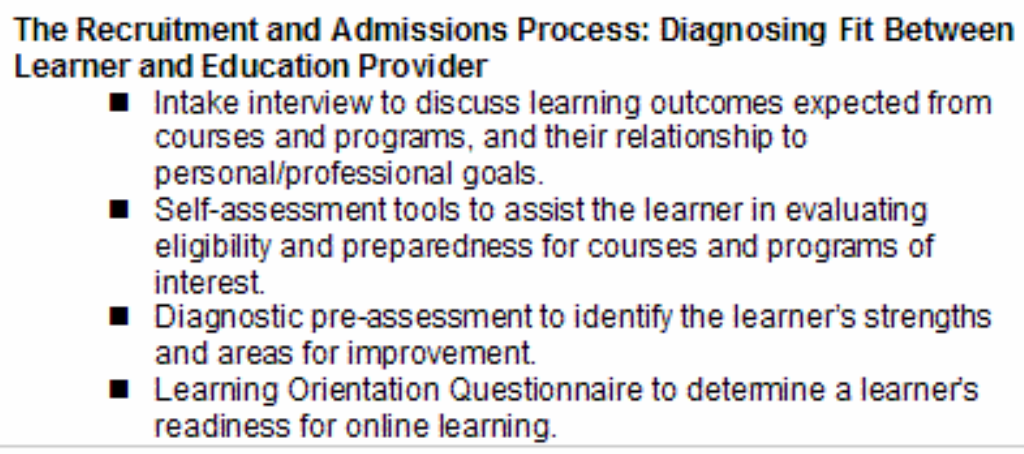

The Recruitment and Admissions Process: Diagnosing Fit Between Learner and Education Provider

- Intake interview to discuss learning outcomes expected from courses and programs, and their relationship to personal/professional goals.

- Self-assessment tools to assist the learner in evaluating eligibility and preparedness for courses and programs of interest.

- Diagnostic pre-assessment to identify the learner's strengths and areas for improvement.

- Learning Orientation Questionnaire to determine a learner's readiness for online learning.

Orientation to the Online Learning Experience: To prepare learners for the responsibilities and expectations of participating in an online course or program in a low-stakes, less-threatening environment.

One-on-one Advising: To have a relationship of support with educational provider staff.

Access to a Community of Learners: To have a sense of connection with the education provider and a sense of community with other learners who have similar leaming plans.

\section{The Recruitment and Admissions Process: Diagnosing fit between learner and education provider}

Learner support services start with making sure that there is an appropriate fit between the students' learning and professional goals and current capabilities with the offerings and structure of the education provider's online programs. This interaction with potential students not only helps them feel immediately connected with the learning community, but the diagnostic activities help them reflect on their learning goals and strategies, a process important to self-directed learning. Recruitment practices can have a big impact on a student's ability to self-assess whether there is a fit, and for the education provider to do the same. For example, WGU, a unique, competency-based institution, recognizes that learners in their distance delivered degree programs need to possess a high level of self-direction and interest in connecting with other learners if they are to be successful. WGU uses specific tools in the recruitment process - such as an intake interview, self-assessment, diagnostic pre-assessment, and Learning Orientation Questionnaire to determine a learner's fit with the institution.

\section{Intake Interview}

Enrollment counselors and other learner support services personnel must be trained to help learners identify their learning needs by asking them questions that require reflection on their current competencies and their desired goals in order to better identify the knowledge gap and plan for instructional opportunities that will address the gap. All new WGU students are required to complete an intake interview with an enrollment counselor. During the intake interview, an enrollment counselor contacts the student via phone to discuss the program in greater detail, help the student assess fit with the institution, and clarify expectations regarding the personal and 
professional commitment needed to succeed. The enrollment counselors ask the following types of questions:

- Why is the learner pursuing higher education? Is it for personal enrichment, advancement in the job market, retooling, retraining, or changing careers?

- Is the learner technology literate? Does the learner have the necessary prerequisite skills to successfully use communication tools such as email, threaded discussions, and chat?

- How many hours per week is the learner willing to commit to studies? Does the learner have the time management skills necessary to block out time to study?

- What is the learner's preferred method of learning? Is the learner comfortable with independent study or does the learner require the structure of instructorfacilitated courses?

- What support structures does the learner have at home or in the workplace?

- What challenges or distractions will the learner encounter (family, work, etc.)? Is the learner willing to treat education as a top priority?

- Has the learner taken distance learning courses in the past? If so, what were the learner's experiences?

The intake interview questions are structured to encourage the learner to articulate their individual needs and goals and, with the help of the enrollment counselor, assess whether WGU is a good fit.

\section{Self Assessment}

WGU requires all learners to complete a self-assessment of their competencies gained through prior work and educational experiences. Using a Web-enabled survey, (http://www.wgu.edu/wgu/student/questionnaire.asp), learners are asked to rank their level of competence from zero (no competence) to three (expert competence) against the competency statements or learning objectives for the degree program. The self-assessment also asks the learner to identify short- and long-term goals, strengths, areas for improvement, and preferred methods of communication.

\section{Diagnostic Pre-Assessment}

All newly admitted WGU students are required to complete a Web-delivered diagnostic preassessment of their competencies in relation to the program requirements. The pre-assessment is used as an advising tool to identify the learner's strengths and areas for improvement.

\section{Learning Orientation Questionnaire}

The Learning Orientation Questionnaire (LOQ), developed by The Training Place (http://www.trainingplace.com), is an online survey that identifies a learner's orientation to learn 
by looking at three psychological factors that influence learning and performance. These factors consider 1) the learner's emotional investment in learning and performance; 2) strategic selfdirectedness; and 3) independence or autonomy - all of which are important to effective selfdirected learning. These three factors are successful learning attributes and describe how learners generally want or intend to approach learning situationally (The Training Place, 2001).

Learning orientations are different from learning styles because orientations emphasize the dominant power of emotions and intentions in learning. "Learning orientations . . . characterize how individuals differ in the ways they choose to plan, set, perform, and attain goals, intend to commit and expend effort, and subsequently experience learning and achievement” (Martinez, 2000, p. 285). The four learning orientations that the LOQ describes are:

- Transforming. WGU learner support services personnel typically recommend independent learning resources for transforming learners because they are highly self-motivated and self-directed and assume responsibility for their learning progress and goals.

- Performing. WGU learner support services personnel recommend a mix of independent learning resources and instructor-facilitated courses for performing learners because they typically respond better to short-term goals and semistructured learning environments.

- Conforming. WGU learner support services personnel recommend instructorfacilitated courses to conforming learners because they typically lack the selfmotivation and direction to learn independently and prefer structured environments.

- Resistant. WGU has not encountered a resistant learner at this time, but would probably counsel a resistant learner out of a distance-delivered program. Resistant learners frequently fail to meet formal learning requirements and expectations.

By providing higher levels of scaffolding through structure and frequent feedback early in the learners' programs, WGU learner support services personnel demonstrate their commitment to help learners move from conforming to performing and from performing to transforming learner orientations. Learner support services personnel assist learners in the development of their selfdirected learning skills by encouraging long term goal setting, development of time management skills, self-assessment of learning progress, and greater learning autonomy.

WGU learner support services personnel utilize the outcomes of the intake interview, selfassessment, diagnostic pre-assessment, and Learning Orientation Questionnaire to predict the extent to which a learner will be successful in WGU programs and to develop the learner's personal learning plan. There are times when learner support services personnel recognize that a student is not a good fit for WGU's distance delivered, competency-based programs and those learners may be counseled to consider other educational options. When there is a disconnect between the learner's goals and priorities and the level of commitment required to be successful in a program, a learner is apt to be dissatisfied and may quit the program or discourage others from considering the institution. 


\section{Orientation to the Online Learning Experience}

Many universities are taking a proactive approach to improving retention, and research bears out the value of a mandatory orientation program (Brawer, 1996; Noel and Levitz, 2000). An orientation program is an education provider's first opportunity to build a community with learners who have actually committed to pursuing their educational goals with the institution.

To be effective, an orientation program needs to provide direction and support for new learners who may be uncomfortable in the distance learning environment. For example, during the early stages of WGU's four week long orientation course, learners are provided with a high level of structure as they become oriented to the community, communication tools, and learning skills needed to work in an online learning environment. As learners begin to show a higher level of comfort with, and interaction in, the environment, the orientation facilitator then encourages learners to take greater responsibility for course content by leading discussions and providing peer feedback. Krauth and Carbajal (1999) further suggest that an orientation should: (a) give students a sense of what it is like to be a distance or online learner; (b) offer tips for being successful in an online learning environment; (c) define technical requirements and prerequisite skills; and (d) describe the steps to access online courses - preferably providing opportunities to practice accessing and navigating through a course. Finding these suggestions to be useful, WGU provides additional information in its orientation courses: (a) suggestions on how learners can create a learning space, develop a study routine, and manage their time assuming a minimum of 10-15 hours per week for their studies; (b) an introduction to research at a distance and how to access the institution's learning resources and e-library; and (c) an introduction to communication tools and skills that will be necessary for students to actively participate in learning communities beyond the orientation course.

WGU's orientation course is an intense introduction to distance learning and WGU's competency-based model of education. By the end of the course, learners are acclimated to the learning community and have practiced applying the self-directed learning skills necessary to be successful in a distance learning environment.

\section{One-On-One Advising}

... I just received your note with my degree completion; "Alleluia and Amen" is right! It's finally finished and I need for you to know that without your help and encouragement, it would not have happened! I don't know how to thank you. It was one of the best days of my life and I shall never forget the hours you spent with me on the phone as you poured over [my degree plan] trying to keep me on track. I was overwhelmed trying to figure out the classes I needed. During difficult classes I would say, "I can't do this; I'm not going to make it." But you kept the faith in me. Because my position within the company I work for required a degree, I felt that I was merely complying with that requirement. However, a few days ago I received a $10 \%$ pay increase as a result of obtaining my degree...Thank you for everything you've done for me.

Excerpt of a letter from a distance learner to her advisor

The positive influence advising can have on distance learners' ability to successfully fulfill their educational goals has been well documented (Feasley, 1983; Hezel and Dirr, 1991; Paulet, 1988; Thompson, 1989), and no more eloquently stated than by the learner who wrote the excerpt 
above. Therefore, a critical learner support service is provision of one-on-one access to advisors (Krauth and Carbajal, 1999). Advisors support learners by helping them identify human and material resources for learning, choose and implement learning strategies, and evaluate learning outcomes. Learners may receive ongoing assistance in such areas as planning academic programs, solving instructional problems, coping with the distance education process, and building skills for career advancement and job hunting. These interactions help students feel connected to the institution while scaffolding self-directness.

WGU's advisors - who are members of the WGU faculty - are called mentors and they work one-on-one with students. Mentors provide individualized guidance to learners in dealing with concerns that influence a) their pursuit of personal and learning goals at a distance; and b) their ability to be more self-directed in their learning. Mentors scaffold student learning by providing the highest level of structure at the beginning of a learner's program through the development of an individualized, detailed Academic Action Plan. Mentors utilize the items gathered during the admissions process - data from the intake interview, self-assessment, diagnostic pre-assessment, and Learning Orientation Questionnaire - to develop the Academic Action Plan that provides a roadmap for the learner's academic program including information about learning resources and assessment dates. Depending on individual learner's needs, mentors provide various levels of scaffolding by:

- Encouraging learners to articulate their learning goals and plans. In the beginning learners need help developing their learning plan and establishing short-term goals so that they gain the skills necessary to manage their goals and plans later in their programs.

- Helping learners understand their learning orientations, strengths, and areas for improvement early in their programs so that they can use this information to develop their plans, goals, and assessment of their learning progress.

- Advising learners on the exploration and selection of learning opportunities that will meet their needs during the initial development of their learning plans. Later, learners will take greater responsibility for identifying their learning resources.

- Guiding learners as they progress toward established goals and encouraging them to evaluate their own progress.

As the mentoring relationship evolves, learners take greater responsibility for their learning goals and strategies. When less support is required, mentors find that they scaffold learners by offering acknowledgment, positive feedback, and encouragement; being an early warning system for unnoted obstacles or potential problems; providing assistance in clarifying and validating learning plans; and by functioning as a responsive problem-solver/ trouble-shooter to assist when academic or administrative issues arise.

\section{Access to a Community of Learners}

Learning is a function of the activity, context, and culture in which it occurs - i.e., it is situated (Wenger, 1998). Successful completion of and satisfaction with an academic experience is directly related to students' sense of belonging and connection to the program and courses (Tinto, 1975). Tinto's (1997) model of institutional departure is one of the most widely recognized student retention models which posits that, "other things being equal, the lower the degree of 
one's social and intellectual integration into the academic and social communities of the college, the greater the likelihood of departure. Conversely, the greater one's integration, the greater the likelihood of persistence" (p. 116). Many of the same motivational effects are evident in contemporary distance education environments, including the same tendency for students to drop out if they lack social interaction with the program (Moore and Kearsley, 1996). Social learning experiences, such as peer teaching, group projects, debates, discussion, and other activities that promote knowledge construction in a social context, allow learners to observe and subsequently emulate other students' models of successful learning. "Successful self-directed learners appear to be highly aware of context in the sense of placing their learning within a social setting in which advice, information, and the skill modeling provided by other learners are crucial conditions for self-directed learning” (Brookfield, 1986, p. 44).

WGU has found that social interaction is a critical component of successful programs and therefore encourages the development of online learning communities. A learning community can be defined as a group of people, connected via technology mediated communication, who actively engage one another in collaborative learner-centered activities to intentionally foster the creation of knowledge, while sharing a number of values and practices, including diversity, mutual appropriation, and progressive discourse. Simply requiring learner interaction in asynchronous environments does not promote a sense of community (Lowell and Persichitte, 2000). WGU has recognized that it cannot force a sense of community through the quantity of interaction, so it strives to support community development by focusing on the nature and quality of interactions.

All of WGU's students have access to a learning community based on the program in which they are enrolled. The learners were introduced to the tools and skills required to actively participate in the community during the orientation course, so most are comfortable with the technology and primarily need support accessing the community itself. Again, WGU mentors provide the greatest scaffolding when new learners are introduced to the community. Mentors invite the learners to join the community and provide detailed instructions on how to access resources, navigate the community, and communicate with other learners via threaded discussions and online chats that are organized by mentors around specific topic areas. As learners move from the periphery of the community to its center, they become more active and engaged with the culture and hence assume the role of expert or 'old-timer.' This process is referred to as legitimate peripheral participation (Lave and Wenger, 1991) and it is an important step in the development of learning community because the expert learners then scaffold new learners as they get acquainted with the community. Expert learners host their own chats and threaded discussions, and provide feedback to mentors about how to improve the resources and tools in the community.

Connection to a learning community provides the social context needed to help learners feel less isolated. Through authentic sharing between learners and instructors, students have opportunities to interact not only on the content and skills being learned (through collaborative projects, team activities, debates, discussions, role-plays, interviews, etc.), but also on topics such as: a) different learning and management approaches and strategies to use; b) resources and references particularly helpful; c) professional and career goals and opportunities; and d) personal interests. This type of interaction - which keeps learners actively connected to the learning environment and education provider - can foster learner competencies, such as self-directed learning skills, because it creates a positive psychological climate built upon trusting human relationships (Knowles, 1990). 


\section{Conclusion}

"The success of distance education, to a greater degree, will depend on the ability of educational institutions to personalize the teaching and learning process" (Saba, 1998, p. 1). Through the use of high-touch, high-interaction learner support services strategies - such as connection to a community of learners and the other scaffolding techniques described in the previous section online students feel less isolated and are immersed in an environment that supports them as they develop or enhance their self-directed learning skills. These types of learner support services proactively address the challenges of online student retention by acknowledging that: "learning is a very human activity. The more people feel they are being treated as human beings - that their human needs are being taken into account - the more they are likely to learn and learn to learn" (Knowles, 1990, p. 129). Although scaffolding to enhance self-direction and reduce isolation should also occur at the course level (see McLoughlin and Marshall, 2000), individual course instructors may be ill prepared to provide the level of scaffolding needed for individual students or may not attend to scaffolding consistently across learning experiences. Learner support services personnel can provide the consistency and individualized attention learners need to be successful in an online learning environment because they are involved with learners throughout their educational experience with the institution. In this way, regardless of the quality or quantity of scaffolding provided by individual instructors, online learners have specific people to work with that know their particular goals, needs, and strengths. WGU has discovered that learner support services can improve the quality of students' academic experiences, connect them to the university, and help them develop the self-directed learning skills that are necessary to succeed in an online learning environment and thus empower them to achieve their learning goals and change their lives. In this way, learner support services can provide scaffolding for success.

\section{References}

Abrahamson, C. E. (1998). Issues in interactive communication in distance education. College Student Journal 32(1), $33-43$.

Abrami, P. C., and Bures, E. M. (1996). Computer-supported collaborative learning and distance education. American Journal of Distance Education 10(1), 37 - 42.

Anton, M. (1999). The discourse of a learner-centered classroom: Sociocultural perspectives on teacher-learner interaction in the second-language classroom. The Modern Language Journal 83(5), $303-318$.

Bennett, S., Priest, A., and Macpherson, C. (1999). Learning about online learning: An approach to staff development for university teachers. Australian Journal of Educational Technology 15(3), 207 - 221.

Besser, H., and Donahue, S. (1996). Perspectives on . . . distance independent education: Introduction and overview. Journal of the American Society for Information Science 47(11), $801-804$.

Booher, R. K., and Seiler, W. J. (1982). Speech communication anxiety: An impediment to academic achievement in the university classroom. Journal of Classroom Interaction 18(1), 23 - 27. 
Brawer, F. B. (1996). Retention-attrition in the nineties. ERIC: ED393510. Los Angeles, CA.: ERIC Clearinghouse for Community Colleges.

Brookfield, D. (1986). Understanding and facilitating adult learning. San Francisco: Jossey Bass.

Brown, K. M. (1996). The role of internal and external factors in the discontinuation of offcampus students. Distance Education 17(1), 44 - 71.

Burak, L. (1993). Independent activities teach skills for lifelong learning. Journal of Health Education 24(5), pp. 376-378.

Carr, S. (2000). As distance education comes of age, the challenge is keeping the students. The Chronicle of Higher Education, February 11, p. A39.

Cohen, N. H. (1995). Mentoring Adult Learners: A guide for educators and trainers. Malabar, FL.: Krieger.

DeVries, J., and Wheeler, C. (1996). The interactivity component of distance learning implemented in an art studio class. Education Journal. Retrieved February 10, 2003 from: http://www2.uiah.fi/ jdevries/intcomp.htm

Dunlap, J. C., and Grabinger, R. S. (2003). Preparing Students for Lifelong Learning: A review of instructional features and teaching methodologies. Manuscript submitted for publication.

ERIC. (1984). Assessing the student attrition problem. ERIC: ED287522. Los Angeles, CA.: ERIC Clearinghouse for Junior Colleges.

Feasley, C. E. (1983). Serving Learners at a Distance: A guide to program practice (ASHE-ERIC Higher Education Research 5). Washington, D.C.: Association for the Study of Higher Education.

Greenfield, P. M. (1984). A theory of the teacher in the learning activities of everyday life. In B. Rogoff and J. Lave (Eds.) Everyday Cognition: Its development in social context. (p. 117138).Cambridge, MA.: Harvard University Press.

Hancock, V. (1993). Information literacy for lifelong learning. ERIC: ED 358870.

Harasim, L., Hiltz, S. R., Teles, L., and Turoff, M. (1995). Learning Networks: A Field Guide to Teaching and Learning Online. Cambridge, MA.: The MIT Press.

Hezel, R. T., and Dirr, P. J. (1991). Barriers that lead students to take television-based college courses. Tech Trends 36(3), $33-35$.

Hill, J. R. (1999). Learning about Distance Education at a Distance: Rewards and challenges. Paper presented at American Educational Research Association, Montreal, Canada, April 19-23.

Hill, J. R., Rezabek, L. R., and Murry, B. (1998). Web-based Instruction: Prospects and challenges. ERIC. ED 414777. 
Kerka, S. (1994). Self-directed learning. Myths and realities. Columbus: ERIC Clearinghouse on Adult, Career, and Vocational Education. ERIC. ED 365818.

Kerka, S. (1995). Adult learner retention revisited. Columbus: ERIC Clearinghouse on Adult, Career, and Vocational Education. (ED 166). Retrieved February 20, 2003 from: http://ericacve.org/docgen.asp?tbl=archive\&ID=A002

Kerka, S. (1999). Self-Directed Learning. Myths and Realities No. 3. Columbus: ERIC Clearinghouse on Adult, Career, and Vocational Education. Retrieved February 10, 2003 from: http://ericacve.org/docgen.asp?tbl=mr\&ID=94

Knowles, M. S. (1975). Self-Directed Learners: A guide for learners and teachers. San Francisco: Jossey-Bass.

Knowles, M. S. (1990). Fostering competence in self-directed learning. In R. M. Smith (Ed.) Learning to learn across the life span. San Francisco: Jossey-Bass, 123 - 136.

Krauth, B., and Carbajal, J. (1999). Guide to developing online student services. Retrieved June 15, 2002 from: http://www.wiche.edu/telecom/resources/publications/guide/guide.htm

Lave, J., and Wenger, E. (1991). Situated Learning: Legitimate peripheral participation. Cambridge, UK.: Cambridge University Press.

Long, H. B. (1994). Challenging some myths about self-directed learning. In H. B. Long and Associates (Eds.) New ideas about self-directed learning (p. 1-14). Norman, OK.: University of Oklahoma.

Lowell, N. O., and Persichitte, K. A. (2000). A Virtual Ropes Course: Creating online community. Asynchronous Learning Network Magazine, 4(1). Retrieved June 17, 2002 from: http://www.aln.org/alnweb/magazine/Vol4_issue1/lowell.htm

Martinez, M. (2000). Successful mentoring, coaching, and guiding relationships from a wholeperson approach. In J. A. Woods and J. W. Cortada (Eds.) The 2001 ASTD Training and Performance Yearbook (p. 283-290). Columbus, OH.: McGraw-Hill.

Maslow, A. (1987). Motivation and personality (3rd ed). New York: Harper \& Row.

McLoughlin, C., and Marshall, L. (2000). Scaffolding: A model for learner support in an online teaching environment. Retrieved February 10, 2003 from: http://cea.curtin.edu.au/tlf/tlf2000/mcloughlin2.html

Moore, M., and Kearsley, G. (1996). Distance Education: A systems view. Belmont, CA.: Wadsworth Publishing Company.

Noel, L., and Levitz, R. (2000). Are college students satisfied? Retrieved June 6, 2002 from: http://www.noellevitz.com/pdfs/Report.pdf

Palincsar, A. S. (1986). The role of dialogue in providing scaffolded instruction. Educational Psychologist, 21, 73 - 98. 
Parker, A. (1999). A study of variables that predict dropout from distance education. Retrieved September 15, 2001 from: http://www.outreach.uiuc.edu/ijet/v1n2/parker

Paulet, R. O. (1988). Factors influencing successful counseling in selected distance education programs. Journal of Research and Development in Education, 21(3), 60 - 64.

Piskurich, G. M. (2002). Preparing learners for online learning. Retrieved February 10, 2003 from: http://www.amanet.org/training zone/archive/hotzone jan2002 02.htm

Rahm, D., and Reed, B. J. (1998). Tangled Webs in Public Administration: Organizational issues in distance learning. Public Administration and Management: An Interactive Journal, 3(1). Retrieved February 10, 2003 from: http://www.pamij.com/rahm.html

Ritchie, H., and Newby, T. J. (1989) Classroom lecture discussion vs. live televised instruction: A comparison of effects on student performance, attitude and interaction. The American Journal of Distance Education, 2, 36 - 43.

Rosenshine, B., and Meister, C. (1992). The use of scaffolds for teaching higher-level cognitive strategies. Educational Leadership, 49(7), 26 - 33.

Saba, F. (1998). Enabling the Distance Learner: A strategy for success. Distance Education Report. Retrieved February 10, 2003: http://distance-educator.com/Editorial_1.2.html

Shea, G. F. (1997). Mentoring. Menlo Park, CA.: Crisp Publications.

Stacey, E. (1999). Collaborative learning in an online environment. Journal of Distance Education, 14(2), 14 - 33. Retrieved February 10, 2003 from: http://cade.icaap.org/vol14.2/stacey.html

Tait, A. (2000). Planning student support for open and distance learning. Open Learning, 15(3), $287-299$.

The Training Place. (2001). Learning Orientation Questionnaire: Measuring online learning ability. Retrieved February 21, 2003 from: http://www.trainingplace.com

Thompson, G. (1989). The Provision of Student-support Services in Distance Education: Do we know what they need? In R. Sweet (Ed.) Post-secondary distance education in Canada: Policies, practices, and priorities. Athabasca, AB.: Athabasca University.

Thompson, G. (1990). How can correspondence-based distance education be improved? A survey of attitudes of students who are not well disposed toward correspondence study. Journal of Distance Education, 5(1), 53 - 65.

Thorpe, M. (2001). Rethinking Learner Support: the challenge of collaborative online learning. SCROLLA Symposium on Informing Practice in Networked Learning. Glasgow, Scotland. Retrieved February 10, 2003 from: http://www.scrolla.ac.uk/papers/s1/thorpe_paper.html

Tinto, V. (1975). Dropout from Higher Education: A theoretical synthesis of recent research. Review of Educational Research, 45(1), 89 - 125. 
Tinto, V. (1997). Classrooms as communities: Exploring the educational character of student persistence. Journal of Higher Education, 68, 599 - 623.

Vygotsky, L. S. (1978). Mind in Society: The development of higher psychological processes. Cambridge, MA.: Harvard University Press.

Wayland, J. P., Swift, C. O. and Wilson, J. W. (1994). Student attitudes toward distance learning. In B. Engelland and A. J. Bush (Eds.) Marketing: Advances in theory and thought (p. 296-299). Southern Marketing Association, November. New Orleans, LA.

Wenger, E. (1998). Communities of practice: Learning, meaning, and identity. Cambridge, UK.: Cambridge University Press.

Wood, D., Bruner, J. S., and Ross, G. (1976). The role of tutoring in problem solving. Journal of Child Psychology and Psychiatry, 17, 89 - 100.

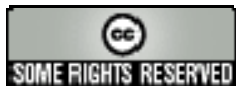

